\title{
Carotid Body Tumor Presented with Lenfadenomegaly; A Rare Case
}

\author{
Lenfadenopati Görünümlü Karotis Cisim Tümörü; \\ Nadir Bir Olgu
}

Olgu Sunumu Case Report

Received/Geliş: 18.09.2019 Accepted/Kabul: 13.02.2020

Published Online: 18.08 .2021

Arif Yüksel

T.C Sağlık Bilimleri Üniversitesi izmir Bozyaka Sağlık Uygulama ve Araştırma Merkezi, iç̧ Hastalıkları Kliniği Izmir - Türkiye ayuksel68@gmail.com ORCID: 0000-0002-8568-5787

S. Uslu 0000-0002-5114-4165 B. Vatansever 0000-0001-9966-0567

Z. Can Erdi 0000-0002-5880-6790

i. Demir 0000-0001-7787-1443

T.C Sağlık Bilimleri Üniversitesi İzmir Bozyaka Sağlık Uygulama ve Araştırma Merkezi, iç Hastalıkları Kliniği İmir - Türkiye

Cite as: Yüksel A, Uslu S, Vatansever B, Can Erdi Z. Demir I. Carotid body tumor presented with lenfadenomegaly: A rare case. Tepecik Exit. lenfadenomegaly; $A$ rare case. Tepecik
Arașt. Hast. Dergisi. 2021;31(2):275-8.

\author{
Arif Yüksel ${ }^{\oplus}$, Serhan Uslu®${ }^{\oplus}$, Bülent Vatansever ${ }^{\oplus}$, Züleyha Can Erdi®, İsmail Demir ${ }^{\oplus}$
}

\begin{abstract}
Carotid body tumors (CBTs) or chemodectomas are non-chromaffin paragangliomas. Carotid body tumors appear as painless, slowly expanding masses located in the upper part of the neck under the chin. On physical examination, it presents as a soft, non-tender mass in the lateral aspect of the neck that can move more freely in a horizontal plane than vertically, referred to as a positive Fontaine sign. The differential diagnosis of a lateral neck mass, rarely seen in adults, includes lymphadenopathy, branchial cleft cysts, salivary gland tumors, neurogenic tumors, and carotid artery aneurysms. A 62-year-old female patient presented with only neck swelling. CBTs are rarely detected in the etiology in cases of lymphadenomegaly. We wanted to present the case to the literature.
\end{abstract}

Keywords: Carotid body tumor, lymphadenomegaly, paraganglioma

Öz

Karotis cisim tümörleri (KCT) veya kemodektomalar kromaffin olmayan paragangliomalardır. Karotis cisim tümörleri, boynun üst kısmında çenenin altında yer alan ağrısız, yavaş yavaş genişleyen kitleler şeklinde ortaya çıkar. Fizik muayenede, lateral boyunda, yatay bir düzlemde dikey olarak olduğundan daha serbestçe hareket edebilen, pozitif bir Fontaine işareti olarak adlandırılan, yumuşak, hassas olmayan bir kitle olarak ortaya çıkmaktadır. Erişkinlerde nadir görülen lateral boyun kitlesinin ayırıı tanısında lenfadenopati, branşial yarık kistleri, tükürük bezi tümörleri, nörojenik tümörler ve karotid arter anevrizmaları bulunur. Altmış iki yașındaki kadın hasta yalnızca boyun şişmesi ile başvurdu. KCT, lenfadenomegali vakalarında etiyolojide nadiren saptanır. Biz vakayı literatüre sunmak istedik.

Anahtar kelimeler: Karotid cisim tümörü, lenfadenomegali, paraganglioma

\section{INTRODUCTION}

Carotid body tumor (CBT) is an uncommon and rarely malignant neoplasm seen in clinical practice,. It accounts for $0.5 \%$ of all head and neck tumors. Approximately $10 \%$ of CBT cases can be bilateral ${ }^{(1-3)}$. Carotid body tumors (CBTs) account for more than $50 \%$ of head and neck paragangliomas ${ }^{(4)}$. Patients can show symptoms of dysphagia, suffocation, and hoarseness due to CBT being in close relation with the cranial nerves. Hereby, we present a case who was admitted with cervical mass diagnosed as a CBT.

\section{CASE}

A woman aged 62 applied to the our clinic with complaints of fever, weakness, and fatigue. Her complaints increased in the last month. On the physical examination, painless, non-pulsative, hard, $3 \times 4 \mathrm{~cm}$ mass in the left anterior triangle of the neck was noticed. It was thought as a lymphadenomegaly. Other physical examination
(C) Telif hakkı TC. Să̆lık Bakanlı̆̆ı izmir Tepecik Eğit. ve Arastt. Hastanesi. Logos Tip Yayınclık tarafindan yayınlanmaktadır.

Bu dergide yayınlanan bütün makaleler Creative Commons Atff-GayriTicari 4.0 Uluslararası Lisansı ile lisanslanmıştır.

(c) Copyright Association of Publication of the T.C. Ministry of Health Izmir Tepecik Education and Research Hospital.

This journal published by Logos Medical Publishing.

Licenced by Creative Commons Attribution-NonCommercial 4.0 International (CC BY) 
findings were normal. On the left costal vertebral line, a $15 \mathrm{~cm}$-long surgical operation scar existed. It was learnt that she had nephrectomy because of a kidney-stone.

Ferritin and hs-CRP remained at high levels and case had symptoms, and signs of anemia. The patient was consulted to the hematology clinic. Possibility of a lymphoreticular system disorder (lymphoma etc.) could not be eliminated. Anemia was thought to be chronic disease anemia. Mass was first reported as $33 \times 24 \mathrm{~mm}$ distinct contoured hypoechoic mass lesion that was located on the left posterior cervical triangle, superimposed on the submandibular salivary gland. MRI was performed for further exami-

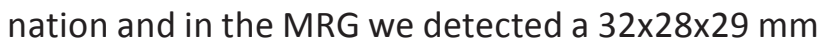
sized mass lesion which was located on the left side of the midline in between, and also extending to the internal and external carotid arteries. The mass contained signal void vascular structures which uptook significant amount of contrast material (Figure 1).

The contrast characterization of the lesion was first suggested the possibility of lymphadenopathy. Since the lesion containing wide signal ovoid vascular structures was located in between internal and external carotid artery bifurcation, and spread to the vascular structures, the diagnosis of carotid body tumor was considered in differential diagnosis. A few lymph nodes with a short axis of 7-8 $\mathrm{mm}$ were found around the lesion. Infection that caused by high levels of C-reactive protein and hyperemia on the throat was thought to be a secondary reactive lymphadenopathy and empiric antibiotherapy was started. Even though the patient was given ceftriaxone and moxifloxacin for 10 days, size of the lymphadenopathy did not change and no reproduction was found on the cultures. For detailed examination and evaluation of the mass vascularity, a color Doppler ultrasonography of the carotid artery was performed, and on the left side of the neck a semisolid approximately $3,5 \times 3 \mathrm{~cm}$ mass lesion with smooth contours extending to internal and external carotid arteries was found.

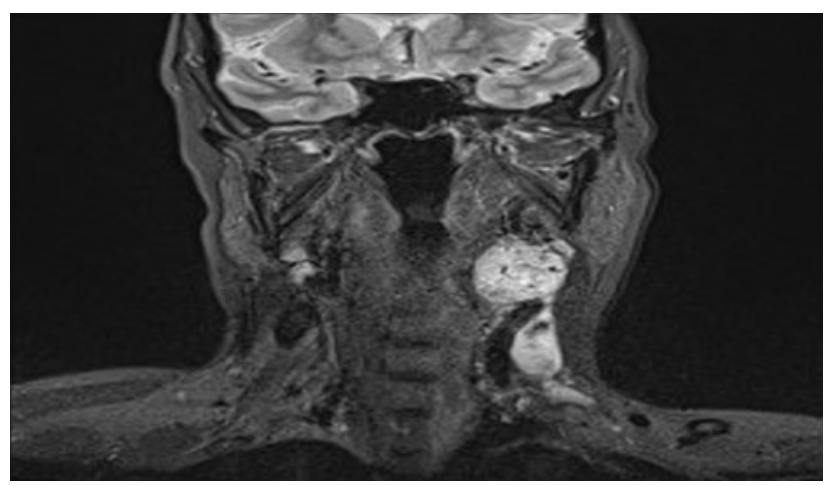

Figure 1. Computed tomography of the neck (anteroposterior view) shows a mass separating the internal and external carotid arteries.

In the color Doppler ultrasonography, the lesion showed intermediate vascularization. It was stated as a significant characteristic feature of a carotid body tumor. No significant malformation and no significant blood flow changes were observed in the carotid body tumor. The patient was operated by the cardiovascular surgery department with the pre-diagnosis of a carotid body tumor. The sample taken from the mass lesion was pathologically diagnosed as a paraganglioma.

\section{DISCUSSION}

Carotid body tumor was first identified in 1743 by Von Haller. Glomus tumors are named by their origin. If they are based on the middle ear tympanic plexus they are identified as "glomus tympanicum", and by the same rule if they are on the ganglion nodosum of the vagus nerve, they are named as "glomus vagale tumor"; if on the carotid bifurcation they are named as "glomus caroticum tumor"(5).

Only $3 \%$ percent of the paragangliomas are based on head-neck area. On this region, CBTs most frequently occur on the carotid bifurcation ${ }^{(6)}$. These tumors are often followed by paragangliomas located on foramen jugularis, middle ear cavity and vagus nerve in order of decreasing frequency . Rarely, these paragangliomas can be seen on orbita, nasal cavity, paranasal sinuses, nasopharynx, larynx, trachea, and the thyroid gland. These paragangliomas are slow developing and usually benign tumors. They must be 
removed when diagnosed, because they exert pressure on the surrounding neural tissues and vascular structures as they grow. Carotid body tumors occur between ages of 40-50 and are seen as a single, asymptomatic, non-functional, space- occupying lesions. They occur more frequently in women than men. Approximately $10 \%$ of paragangliomas are familial and $90 \%$ of them are sporadic ${ }^{(7)}$. Heritability among family is autosomal dominant but penetrance is different ${ }^{(8)}$. In less than $5 \%$ of the patients who have the sporadic form these tumors occur bilaterally. However these tumors occur bilaterally in only $1 / 3$ of the patients with a history of heritability. Carotid body tumor is usually diagnosed as an asymptomatic mass during the examination of patients who came for asymptomatic head-neck mass inspection. Other symptoms are dizziness, pain in the same area where mass exists, palpitation, flushing on the face, and, the feeling of paraesthesia (9). In the differential diagnosis of the case, enlarged lymph nodes, carcinoma metastasis, parotid gland tumors, branchial cleft cysts, neurolemmas, and, carotid artery aneurysms should be considered ${ }^{(1,10)}$. As treatment alternatives as surgical procedures or embolization can be performed. A categorization which was done by Shamblin ${ }^{(11)}$ in 1971 is taken as a basis in the surgical treatment of the CBT. According to this categorization, class- 1 tumors are small, less sticky to the carotid arteria and amenable to surgical resection. Class- 2 tumors are bigger with little arterial connections and need to be carefully resected. Class-3 tumors are big, surround all around the carotid artery and need resection of the artery ${ }^{(12,13)}$.

Normally a carotid body vascularized by an artery that branches from carotid bifurcation has a diameter of 1-2 mm. Normal size of a caroid body may vary, but on an average it has dimensions of $5 \times 3 \times 1,5$ $\mathrm{mm}$. In adults, its average weight is $12.1 \mathrm{mg}$ that varies between 1-47.4 mg. Carotid body sustains autonomic control of the respiratory and cardiovascular system. Paraganglionic cells that form this structure sense the changes of $\mathrm{pO}_{2}$ ve $\mathrm{pCO}_{2}$ in the blood ${ }^{(2,14)}$.

Carotid body tumors are slow-growing tumors that originate from chemoreceptor tissue on the carotid bifurcation. Slowly growing diffuse mass in the neck, at the level of the hyoid bone, in front of sternocleido-mastoid muscle should be considered as a CBT.

Classically mass can be moved to the lateral side but can not be moved medially as it sticks to the carotid artery. This called the "Fontaine sign"(15). Sometimes during auscultation, a murmur can be heart. As seen in our case, the patient applied to the clinic for the examination of an asymptomatic mass that can be palpated that exist for a month. In our patient, no family history existed.

Etiology of the CBT is unknown. Increasing incidence of CBT in those who live at high altitudes above the sea level and those who have chronic obstructive pulmonary disease, make us think that chronic hypoxia is a cause of CBT. Often CBTs are benign tumors but $3 \%$ percent of them demonstrate a malign transformation ${ }^{(16)}$. The histo-pathologic analysis is a weak sign of a malign potential. This is why malignancy was considered as the existence distant metastases. Approximately $5 \%$ of the metastases can occur generally to the regional lymph nodes, often to the brachial plexus, cerebellum, lungs, bones, abdomen, thyroid, and the nipples ${ }^{(16)}$. Ninety-five percent of all the CBTs are benign. However they are also locally aggressive tumors that have a growth rate of $2 \mathrm{~cm}$ in every 5 years and can cause regional mass affects and neurological dysfunctions due to pressure on or infiltration into adjacent structures (17). If the mass considered as a CBT on the next stage ultrasonography, technetium isotope scintigraphy, computed tomography, magnetic resonance screening, MRI angiography, and in case of need, a conventional angiography can be performed. In the screening of a carotid tumor, the gold standard is angiography. Digital spiral angiography, spiral CT angiography, and color Doppler screening can be used preoperative diagnostic tools. These inspections were performed on our patient as well and she was operated by consulting the cardiovascular department. 
When choosing a treatment, age of the patient, symptoms, size, and growth rate of the tumor, the general health condition of the patient should be considered. Surgical treatment is a standard approach to the carotid body tumors for the last several years. Recurrence is very rare, but patients should be closely monitored for any local recurrence ${ }^{(17)}$. In case of a finding of a mass that was localized in the neck, these rare cases should be considered and we wanted to share this case with literature platform.

Conflict of Interest: None of the contributing authors have any conflict of interest.

Informed Consent: In formed consent was taken from the patient.

\section{REFERENCES}

1. Singh D, Pinjala RK, Reddy RC, Satya Vani PVNL. Management for carotid body paragangliomas. Interact Cardiovasc ThoracSurg. 2006;5(6):692-5. [CrossRef]

2. Ünlü Y, Becit N, Ceviz M, Koçak H. Management of Carotid BodyTumorsand Familial Paragangliomas: Review of 30 Years' Experience. Ann Vasc Surg. 2009;23(5):616-20. [CrossRef]

3. Martinelli O, Irace L, Massa R, et al. Carotid body tumors: Radioguided surgical approach. Ital J Vasc Endovasc Surg. 2009;28:148. [CrossRef]

4. Rao AB, Koeller KK, Adair CF. From the archives of the AFIP. Paragangliomas of the head and neck: radiologic-pathologic correlation Armed Forces Institute of Pathology Radiographics 1999;19:1605-32. [CrossRef]
5. Vogl TJ, Juergens M, Balzer JO, et al. Glomus tumors of the skull base: Combined use of MR angiography and spin- echo imaging. Radiology. 1994;192(1):103-10. [CrossRef]

6. Lack EE, Cubilla AL, Woodruff JM, Farr HW. Paragangliomas of the head and neck region. A clinical study of 69 patients. Cancer. 1977;39(2):397-409. [CrossRef]

7. Phitayakorn R, Faquin W,Wei N, Barbesino G, E.Stephen A. Thyroid-Associated Paragangliomas. Thyroid. 2011;21(7):72533. [CrossRef]

8. Van Gils APG, Van Der Mey AGL, Hoogma RPL, et al. Mri screening of kindred at risk of developing paragangliomas: Support for genomic imprinting in hereditary glomus tumours. Br J Cancer. 1992;65(6):903-7. [CrossRef]

9. Wieneke JA, Smith A. Paraganglioma: Carotid Body Tumor. Head Neck Pathol. 2009;3(4):303-6. [CrossRef]

10. Van Der Mey AGL, Jansen JC, Van Baalen JM. Management of carotid body tumors. Otolaryngol Clin North Am. 2001;34(5):907-24. [CrossRef]

11. Shamblin WR, ReMine WH, Sheps SG, Harrison EG. Carotid body tumor (chemodectoma). Clinicopathologic analysis of ninety cases. Am J Surg. 1971;122(6):732-9. [CrossRef]

12. Arya S, Rao V, Juvekar S, Dcruz AK. Carotid body tumors: Objective criteria to predict the Shamblin group on MR imaging. Am J Neuroradiol. 2008;29 (7):1349-54. [CrossRef]

13. Netterville JL, Reilly KM, Robertson D, Reiber ME, Armstrong WB, Childs P. Carotid body tumors: A review of 30 patients with 46 tumors. Laryngoscope. 1995;105:115-26. [CrossRef]

14. Baysal BE, Myers EN. Etiopathogenesis and clinical presentation of carotid body tumors. Microsc Res Tech. 2002;59(3):25661. [CrossRef]

15. Kaygusuz I, Karlidag T, Keles E, Yalcin S, Yüksel K. Carotid Body Tumor. Journal of Craniofacial Surgery, 2015;26(7):e586e589. [CrossRef]

16. Makeieff M, Raingeard I, Alric P, Bonafe A, Guerrier B, MartyAne $C$. Surgical management of carotid body tumors. Ann Surg Oncol. 2008;15(8):2180-6. [CrossRef]

17. Bakshi SS, Kumar TL. Carotid Body Tumor. Journal of Pediatric Hematology/Oncology. 2018;40(2):143-4. [CrossRef] 